\title{
Production of Starch-Based Bioplastic from Durio zibethinus Murr Seed Using Glycerol as Plasticizer
}

\author{
Nanda Raudhatil Jannah ${ }^{1}$, Novesar Jamarun ${ }^{2 *}$, Yulia Eka Putri ${ }^{2}$ \\ ${ }^{1}$ Universitas Muhammadiyah Bandung, West Java, Indonesia \\ ${ }^{2}$ Department of Chemistry, Faculty of Mathematics and Natural Sciences, Universitas Andalas, West \\ Sumatra, Indonesia
}

\author{
Corresponding Author: \\ Novesar Jamarun \\ novesar62@yahoo.com \\ Received: February 2021 \\ Accepted: August 2021 \\ Published: September 2021 \\ CNovesar Jamarun et al. This \\ is an open-access article \\ distributed under the terms \\ of the Creative Commons \\ Attribution License, which \\ permits unrestricted use, \\ distribution, and \\ reproduction in any medium, \\ provided the original author \\ and source are credited.
}

\begin{abstract}
Bioplastics are bio-based plastics from natural resources, made to replace conventional plastics. The utilization of biopolymers in bioplastics provide a faster degradation compared to petroleum-based plastics. Starch-based bioplastic from mixing Durio zibethinus Murr starch and glycerol as plasticizer have been conducted. In this research, the concentration of glycerol has been varied to study the effect on starch-based bioplastics mechanical properties. The tensile strength for Durio zibethinus Murr starchbased bioplastic with $20 \%$ glycerol was $50.28 \mathrm{MPa}$ with $13.3 \%$ elongation. The functional group found on the Fourier transform infrared spectroscopy (FTIR) spectra indicated the presence of $\mathrm{O}-\mathrm{H}$ stretch, $\mathrm{C}-\mathrm{H}$ stretch, $\mathrm{C}=\mathrm{O}$ stretch, and C-O stretch which stated the formation of bioplastic. The image results gained from scanning electron microscope (SEM) showed that the morphology surface of bioplastic was less homogenous and rough. The soil burial test for biodegradability showed Durio zibethinus Murr starch-based bioplastic achieved $38.9 \%$ weight loss in a 5-day observation.
\end{abstract}

Keywords: bioplastics, Durio zibethinus Murr starch, glycerol, tensile strength

\section{Introduction}

Plastic is widely used as packaging material and other applications due to its several advantages such as being light, durable, cheap, and has thermoplastic characteristics. As the human population increases, the plastic demand will also increase. Conventional plastics can not be degraded and leads to environmental issues such as global warming, climate change, etc ${ }^{[1]}$. This problem raises an idea for producing plastics from other sources that are environmentally friendly. One of the solutions is the utilization the use of natural sources as an alternative ingredient to produce bioplastics or biodegradable plastics. The biodegradability of bioplastics will decrease the pollution caused by petroleum-based plastics and reduce the amount of plastic waste ${ }^{[2]}$.

Starch-based bioplastics can be produced by using starch of a plants such as cassava ${ }^{[3]}$, potatoes and yam ${ }^{[4]}$, corn and rice ${ }^{[5]}$ and Durian (Durio zibethinus Murr) seed ${ }^{[6]}$. The advantages of using starch as raw materials are cheap and renewable. However, the use of starch from food sources causes competition with basic needs, especially cassava, potatoes and corn. Therefore, 
utilizing the starch from food waste can be a viable option. Starch-based bioplastics from Durio zibethinus Murr seed have a lower cost than other sources, so it can be an applicable choice to use food waste to produce useful products.

Durian (Durio zibethinus Murr) is a seasonal fruit that is found in the tropics in Indonesia. During this time, part of the commonly consumed Durian is the fruit, while the bark and seeds have not been fully utilized and more turn into waste. Ripe of durian seeds containing 51.1\% water, $46.2 \%$ carbohydrate, $2.5 \%$ protein and $0.2 \%$ lipid[7]. High carbohydrate contains in Durio zibethinus Murr seed make it capable to be the source of making bioplastics ${ }^{[8]}$.

Starch-based materials have attracted the researcher's attention due to their advantages, especially their biodegradable properties, lowcost production, and renewable ${ }^{[4]}$. The mechanical properties of plastics are influenced by the composition of the constituent components. Plastic films based on starch alone have low tensile strength and elongation, so it is necessary to add a plasticizer to improve their mechanical properties. However, the moisture content and plasticity of starch are highly dependent on the temperature and humidity of plastic storage, making it less efficient to apply ${ }^{[9]}$.

Many efforts have been exerted to develop starch-based bioplastic by combining it with plasticizers, such as glycerol. Hydrophilic and hygroscopic properties of glycerol are expected to increase the stability of the plastic film ${ }^{[3]}$. The plasticizer could form the hydrogen bonds with starch, take the place of the strong interaction between intra- and intermolecular hydrogen bonds in starch, and make starch display the plasticization and gives the elastic properties to the bioplastics ${ }^{[10]}$.

In this study, the ability to use Durio zibethinus Murr starch to produce bioplastic with the addition of various concentration of glycerol as plasticizer was determined. The mechanical properties, the functional group that exist, and biodegradable properties of the product were also characterized to evaluate the potential of bioplastic as a suitable alternative to reduce the existing conventional plastics.

\section{Experimental}

\section{Materials}

The materials used for production starch-based bioplastic were Durio zibethinus Murr seed, was collected from Payakumbuh. Glycerol and lime water $\left(\mathrm{Ca}(\mathrm{OH})_{2}\right)$ were purchased from Andeska Laboratory, Padang. Distilled water was obtained from Material Chemistry Laboratory, Department of Chemistry, Universitas Andalas.

\section{Instruments}

The testing equipment used were Fourier transform infrared spectroscopy (FTIR Perkin Elmer 1600 series), scanning electron microscope (SEM Hitachi S-3400N) and tensile strength test with COM-TEN Testing Machine 95T Series.

\section{Methods}

\section{Extraction of Durio zibethinus Murr starch}

To extract the starch, $20 \mathrm{~kg}$ of Durio zibethinus Murr seed were weighed and washed. The seeds were peeled and cut into small pieces. Then it soaked in $10 \mathrm{~L}$ of lime water for $12 \mathrm{~h}$ to remove the sap. The durian seeds are then drained and washed with clean water and after that dried under sunlight. Dried durian seeds were blended and added with water in a ratio of 1:2, then squeezed and the filtrate was taken. The filtrate was allowed for $12 \mathrm{~h}$ to obtain a precipitate. The precipitate was taken and dried under sunlight for $48 \mathrm{~h}$, and obtained durian seed starch. The Durian seed starch is sieved to get a smaller and same size.

\section{Production of starch-based bioplastic}

Table 1 shows the composition of prepared bioplastics. Starch-Based Bioplastic was made by dissolved $10 \mathrm{~g}$ of starch in the water while stirring for $5 \mathrm{~min}$ at $90{ }^{\circ} \mathrm{C}[8]$. Then, glycerol with a variation concentration of $10 \%, 15 \%, 20 \%, 25 \%$, $30 \%$ was added to the mixing solution. The mixture was poured into a mould with size 19.5 $\mathrm{cm} \times 19.5 \mathrm{~cm}$ and dried in an oven at $45^{\circ} \mathrm{C}$ for 30 min and then cooled at room temperature for 24- 
$48 \mathrm{~h}$. Finally, the starch-based bioplastic in sheet form was obtained[3].

\section{Tensile strength test}

The tensile strength test was performed using the COM-TEN testing Machine 95T Series. Five samples with variation concentration of glycerol were tested according to ASTM D638 for plastic polymers.

\section{SEM analysis}

Bioplastic samples with high tensile test values were followed by examination of morphological characteristics using scanning electron microscopy (SEM). Plastic film size $1 \mathrm{~cm}^{2}$ was observed using an accelerating voltage of $10 \mathrm{kV}$.

\section{FTIR analysis}

FTIR characterization was used to determine the functional groups in bioplastic, compared with functional groups in Durio zibethinus Murr starch to estimate the types of interactions that occur in the bioplastics product.

\section{Biodegradability test}

The biodegradability test was carried out using the soil burial test technique ${ }^{[5]}$. Bioplastics were cut into $2 \times 1 \mathrm{~cm}^{2}$ size and buried in the soil and exposed to open air without being covered with glass. Observations of the sample were carried out for 5 days.

Biodegradability calculation:

$$
\% \text { Biodegradability }=\frac{\text { Initial weight-Final weight }}{\text { Initial weight }} \times 100 \%
$$

\section{Results and Disscusion}

\section{Durio zibethinus Murr starch-based bioplastic}

Table 2 below presents the content of amylose and amylopectin in Durio zibethinus Murr starch. The ratio of amylose and amylopectin causes the gelatinization temperature used during the bioplastic formation process. Amylopectin has a larger molecule than amylose. This causes the amylopectin granules to take a long time to begin to gelatinize ${ }^{[11]}$.

Table 1. Composition of prepared bioplastics

\begin{tabular}{cccc}
\hline Sample & Durian Starch $(\mathbf{g})$ & Glycerol $(\mathbf{m L})$ & Water $(\mathbf{m L})$ \\
\hline Sample 1 & 10 & 1 & 100 \\
Sample 2 & 10 & 1.5 & 100 \\
Sample 3 & 10 & 2 & 100 \\
Sample 4 & 10 & 2.5 & 100 \\
Sample 5 & 10 & 3 & 100 \\
\hline
\end{tabular}

Table 2. Characteristic of Durio zibethinus Murr starch

\begin{tabular}{ccc}
\hline No. & Components & Percentage \% \\
\hline 1. & Amylose & $3.21 \%$ \\
2. & Amylopectin & $96.79 \%$ \\
\hline & Total & $\mathbf{1 0 0} \%$ \\
\hline
\end{tabular}




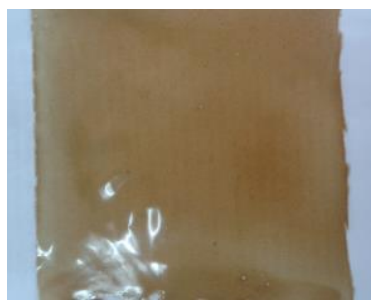

Figure 1. Durio zibethinus Murr starch-based bioplastic.

Figure 1 shows the starch-based bioplastic Durio zibethinus Murr. The color of the bioplastic is slightly brown and smells of durian fruit.

\section{Mechanical properties of bioplastic}

Figure 2 shows the tensile strength and elongation of Durio zibethinus Murr starch-based bioplastic with various concentrations of glycerol. The graph of tensile strength and elongation increases due to the addition of glycerol until 20\%. Increasing more glycerol decrease the tensile strength and elongation value. In the presence of water and glycerol as plasticizer, the strong intramolecular and intermolecular hydrogen bonds in starch can be weakened ${ }^{[12]}$. It is called "anti-plasticization" properties that make a material become stiff and brittle ${ }^{[3]}$. On the other hand, decreasing glycerol addition in bioplastic causes lower tensile strength due to the interaction between starch and glycerol has not been achieved. It would also affect the flexibility of bioplastic. The maximum tensile strength and elongation values were achieved at $20 \%$ glycerol with a tensile strength value of $50.28 \mathrm{MPa}$ and $13.3 \%$ elongation. This result occupies SNI standards (24.7-302 MPa) as plastic packaging while the elongation value does not meet the standard (21$220 \%$ ) yet[13].

\section{FTIR analysis}

The FTIR spectra of Durio zibethinus Murr starch and bioplastic product are shown in Figure 3. The spectra of figure $3 a$ and $b$, shows the specific hydroxyl $(\mathrm{O}-\mathrm{H})$ at $3200-330 \mathrm{~cm}^{-1}, \mathrm{C}-\mathrm{O}$ stretch at $1000-1150 \mathrm{~cm}^{-1}, \mathrm{C}-\mathrm{H}$ stretch at $2700-2900 \mathrm{~cm}^{-1}$, and $\mathrm{C}=\mathrm{O}$ stretch at $1600-1820 \mathrm{~cm}^{-1}$. FTIR results show that there were no new functional groups found in the bioplastic spectra compared to the starch. The presence of $\mathrm{C}-\mathrm{O}$ and $\mathrm{C}=\mathrm{O}$ functional groups in bioplastics indicates that the product had the ability to be degraded.
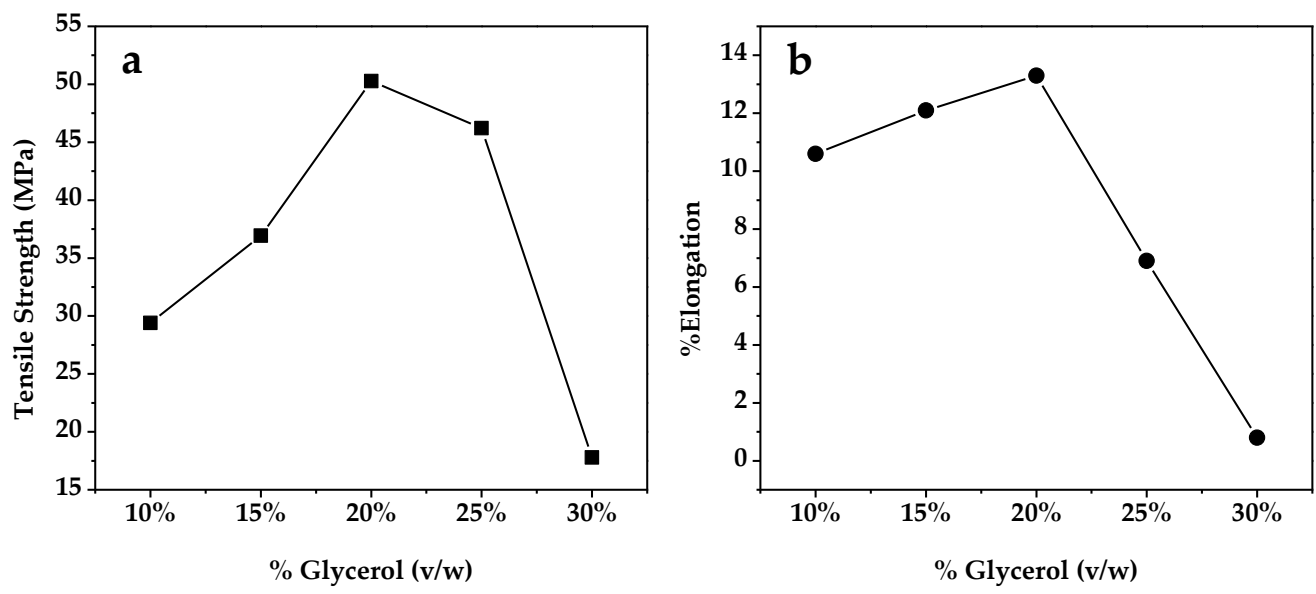

Figure 2. Mechanical properties of Durio zibethinus Murr starch-based bioplastic a) tensile strength and b) elongation, with various concentration of glycerol. 


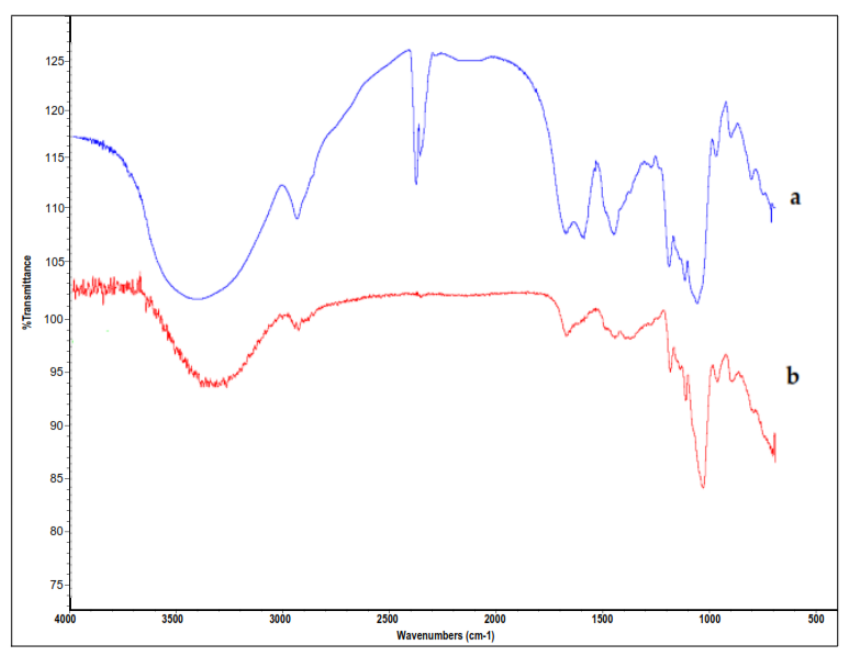

Figure 3. FTIR spectrum of a) Durio zibethinus Murr starch and b) Durio zibethinus Murr starch-based bioplastic with $20 \%$ glycerol.

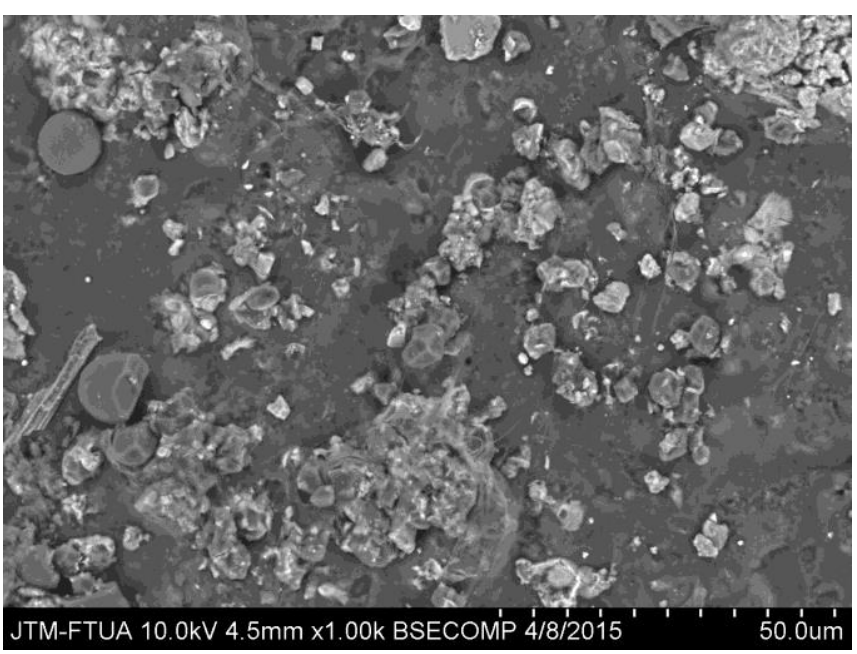

Figure 4. Durio zibethinus Murr starch-based bioplastic with 20\% glycerol (1000 x).

Bioplastic component such as starch and glycerol have hydrophilic properties which bind water molecules from around the environment and facilitate degradation ${ }^{[14]}$.

\section{SEM analysis}

Figure 4 shows the surface morphology of the Durio zibethinus Murr starch-based bioplastic. It can be seen that the bioplastic surface is less homogeneous and rough. On heating starch with water, a phase transition of the starch called gelatinization occurs. Swelling power and solubility provide evidence of interactions between water molecules and starch chains in amorphous and crystalline domains of the starch granules ${ }^{[8]}$. Thus, the insoluble remnants of the starch granule swelling process are clearly visible on SEM[15]. These results could also affect the elongation properties of the bioplastics.

\section{Biodegradabilty test}

The following Table 3 gives the weight loss conducted by Durio zibethinus Murr starch-based bioplastic with $20 \%$ glycerol in 5 days of soil burial test. 
Table 3. Biodegradability test of Durio zibethinus Murr starch-based bioplastic

\begin{tabular}{llll}
\hline \multicolumn{1}{c}{ Sample } & $\begin{array}{c}\text { Wo }_{\text {o }} \\
(\text { gram })\end{array}$ & $\begin{array}{c}\text { W5 } \\
\text { (gram) }\end{array}$ & \%Biodegradabilty \\
\hline $\begin{array}{l}\text { Durio zibethinus } \\
\text { Murr starch- } \\
\text { based bioplastic } \\
\text { with 20\% }\end{array}$ & 0.2840 & 0.1734 & \%Biodegradability $=\frac{\text { Initial weight-Final weight }}{\text { Initial weight }} \times 100 \%$ \\
glycerol & & & $=\frac{0.2840-0.1734 \mathrm{~g}}{0.2840 \mathrm{~g}} \times 100 \%=38.9 \%$ \\
\hline
\end{tabular}

$\mathrm{W}_{0}=$ initial weight and $\mathrm{W}_{5}=$ final weight of bioplastic
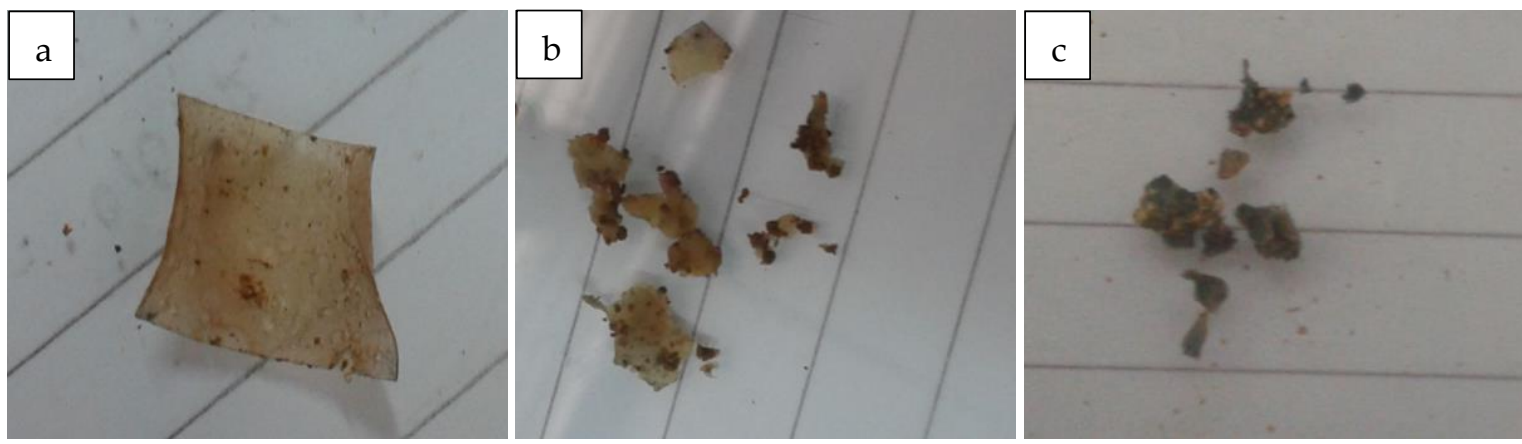

Figure 5. Durio zibethinus Murr starch-based bioplastic biodegradation test on soil a) day-0, b) day-5, c) day-7.

No soil preparation was used in the biodegradability test. This aims to see the biodegradability process of bioplastics if buried in open ground which in this study uses soil taken outside the laboratory.

The presence of glycerol in plastic will bind moisture in the air. This causes bioplastics to easily absorb water in the soil so that the swelling of plastic films becomes greater which causes the plastic to be more easily broken into fragments that will be easily degraded by bacteria or fungi in the soil[10]. The weight loss of bioplastic was calculated to examined bioplastics biodegradability. The hydroxyl, O-H groups contain in starch-based bioplastic lead the hydrolysis after absorbing water from compost and increased the decomposition process ${ }^{[3]}$. The polymer chains in starch are broken and cause the weight loss of bioplastic film during burial in soil indicates the amount of degradation by microorganisms ${ }^{[10]}$.
According to the calculation, Durio zibethinus Murr starch-based bioplastic has 38.9\% biodegradation for 5 days soil burial test. Figure 5 show the plastic film damage after being buried in the soil from day-0 until day-5, on day7 the plastic film was broken down and blend with the soil, so it can not weigh precisely. Thus, it is required longer times to be completely degraded.

\section{Conclusions}

Starch-based bioplastics are renewable use for making bioplastics to replace conventional plastics. The addition of various glycerol concentrations affected the tensile strength and elongation values of bioplastics. The optimum conditions for making Durio zibethinus Murr starch-based bioplastics were obtained in a mixture of $20 \%$ glycerol as a plasticizer with a tensile strength value of $50.28 \mathrm{MPa}$ and $13.3 \%$ of elongation. FTIR results showed that the 
presence of $\mathrm{C}-\mathrm{O}$ ester and $\mathrm{C}=\mathrm{O}$ carbonyl groups in bioplastics indicates that the starch-based bioplastic had the ability to degraded and it showed in the biodegradability test which revealed $38.9 \%$ of bioplastics broke down in 5 th day. The SEM image of bioplastic indicated that the gelatinization of starch is not complete so that the morphology is less homogeneous and rough. It is necessary to vary the plasticizer used and also the addition of filler to improve the mechanical properties of the bioplastic.

\section{Acknowledgments}

This work was financially supported by Ministry of Higher Education, Indonesia through PKM-PE program.

\section{References}

1. Reddy, R. L., Reddy, V. S. \& Gupta, G. A., Study of bio-plastics as green and sustainable alternative to plastics. Int. J. Emerg. Technol. Adv. Eng., 3(5): 76-81 (2013).

2. Rahman, A., Syamsu, K. \& Isroi., Biodegradability of bioplastic from oil palm empty fruit bunch. J. Nat. Resour. Environ. Manag., 9(2): 259-264 (2017).

3. Wahyuningtiyas, N. E. \& Suryanto, H., Properties of cassava starch based bioplastic reinforced by nanoclay. J. Mech. Eng. Sci. Technol., 2(1): 20-26 (2018).

4. Ismail, N. A., Mohd Tahir, S., Yahya, N., Abdul Wahid, M. F., Khairuddin, N. E., Hashim, I., Rosli, N., et al., Synthesis and characterization of biodegradable starchbased bioplastics. in Materials Science Forum, 846: 673-678 Trans Tech Publications Ltd, (2016).

5. Marichelvam, M. K., Jawaid, M. \& Asim, M., Corn and rice starch-based bio-plastics as alternative packaging materials. Fibers, 7(4): 1-14 (2019).

6. Ginting, M. H. S., Hasibuan, R., Lubis, M., Tanjung, D. S. \& Iqbal, N., Effect of hydrochloric acid concentration as chitosan solvent on mechanical properties of bioplastics from durian seed starch (Durio zibethinus) with filler chitosan and plasticizer sorbitol. in IOP Conference Series: Materials Science and Engineering, 180(1): 012126 IOP Publishing, (2017).

7. Zuraida, A., Yusliza, Y., Anuar, H. \& Muhaimin, R. M. K., The effect of water and citric acid on sago starch bio-plastics. Int. Food Res. J., 19(2): 715-719 (2012).

8. Baraheng, S. \& Karrila, T., Chemical and functional properties of durian (Durio zibethinus Murr.) seed flour and starch. Food Biosci., 30: 100412 (2019).

9. Avérous, L. \& Pollet, E., Biodegradable polymers. in Environmental Silicate NanoBiocomposites, (eds. Avérous, L. \& Pollet, E.), Springer, 13-39 (2012).

10. Lu, D. R., Xiao, C. M. \& Xu, S. J., Starchbased completely biodegradable polymer materials. Express Polym. Lett., 3(6): 366-375 (2009).

11. Dureja, H., Khatak, S., Khatak, M. \& Kalra, M., Amylose rich starch as an aqueous based pharmaceutical coating materialreview. Int. J. Pharm. Sci. Drug Res., 3(1): 812 (2011).

12. Tudorachi, N., Cascaval, C. N., Rusu, M. \& Pruteanu, M., Testing of polyvinyl alcohol and starch mixtures as biodegradable polymeric materials. Polym. Test., 19(7): 785-799 (2000).

13. Anggarini, F., Latifah, L. \& Miswadi, S. S., Aplikasi plasticizer gliserol pada pembuatan plastik biodegradable dari biji nangka. Indones. J. Chem. Sci., 2(3): 173-178 (2013).

14. Septiosari, A., Latifah, L. \& Kusumastuti, E., Pembuatan dan karakterisasi bioplastik limbah biji mangga dengan penambahan selulosa dan gliserol. Indones. J. Chem. Sci., 3(2): 157-162 (2014).

15. Amin, M. R., Chowdhury, M. A. \& Kowser, M. A., Characterization and performance analysis of composite bioplastics synthesized using titanium dioxide nanoparticles with corn starch. Heliyon, 5(8): e02009 (2019). 